\title{
Corporate Ownership, Corporate Control and Corporate Performance in Sub-Saharan African: Evidence from Nigeria
}

\author{
Ioraver N. Tsegba ${ }^{1}$, Wilson E. Herbert ${ }^{2} \&$ Emeka E. Ene ${ }^{2}$ \\ ${ }^{1}$ Department of Accounting \& Finance, Federal University of Agriculture, Makurdi, Nigeria \\ ${ }^{2}$ Department of Accounting, Bingham University, Karu, Nasarawa State, Nigeria \\ Correspondence: Wilson E. Herbert, Department of Accounting, Bingham University, Karu, Nasarawa State, \\ Nigeria. Tel: 234-803-602-5258. E-mail: wilson@eziherbert.com
}

Received: September 4, 2014

doi:10.5539/ibr.v7n11p73
Accepted: September 25, 2014

Online Published: October 25, 2014

URL: http://dx.doi.org/10.5539/ibr.v7n11p73

\begin{abstract}
This paper investigates the relation between corporate ownership and corporate performance of listed companies in Nigeria, a foremost Sub-Saharan African country during the period 2002-2007. The data is obtained from the firms' annual reports and accounts and the Nigerian Stock Exchange daily performance reports. The combination of 70 firms and six-year period studied provides a balanced panel with 420 observations for panel data analysis. The results from the ordinary least square (OLS) regression analyses show that there is a strong connection between foreign ownership structure and firm performance. Foreign ownership structure is found to exhibit significant improvements in firm performance; it adumbrates eclectic competitive advantages in ownership, control and internalization respects over other types of ownership structure. We find no statistically significant relation between concentrated ownership and firm performance. Insider or managerial ownership, however, exhibits significant decline in firm performance. These findings are consistent with the view that firm performance is a negative predictor of insider ownership. We also find support for the notion that management is apathetic to holding equity stakes in their underperforming firms.
\end{abstract}

Keywords: corporate ownership structure, corporate control, corporate performance, Sub-Sahara Africa, Nigeria

\section{Introduction}

The connection between corporate ownership structure and corporate performance has been and still is a contentious issue in the corporate finance literature since 1932 when Berle and Means stirred the hornet's nest with the postulation that an inverse relation exists between corporate ownership structure and corporate performance. By recognizing the centrality of ownership structures in resolving the problems associated with separation of ownership and management, their seminal work not only laid the foundation for the central premise of the agency theory and associated research but also for the spate of research examining corporate ownership structures in what can be characterized as the ownership-performance debate (OPD). The OPD deserves special attention in emerging and transition economies where wholesale privatization and commercialization of state-owned enterprises (SOEs) have become crucial aspects of economic reforms. To be sure, economic reforms of the privatization genre have implications for ownership structure and concentrated control, corporate governance, and firm performance.

The OPD is about the relation between ownership structures and firm performance, specifically in the presence of diffuse or multidimensional ownership which was at the heart of Berle and Means' treatise. Studies that have investigated dimensions of this relationship are legion. For instance, Kapopoulos and Lazaretou (2006) in Greece, Farooque, Zijl, Dunstan and Karim (2007) in Bangladesh, Pivovarsky (2003) in Ukraine, Adenikinju and Ayorinde (2001), Sanda, Mikailu and Garba (2005), and Tsegba and Herbert (2011; 2013) in Nigeria, investigated the relationship between various ownership structures such as largest shareholder, concentrated ownership, insider ownership, and foreign ownership, on firm performance. Even though the results of these studies are mixed, a unique feature of the investigations is the use of ownership as a corporate governance mechanism. Along with other researchers, we construe corporate governance as the mechanisms put in place by shareholders to ensure firm resources are not expropriated by entrenched management.

Research about ownership of firms and how they are governed is centrally premised on the agency theoretical 
framework. It is predicated on the notion that tension exists between shareholders and managers on account of their separation of ownership and control. Above all, the managerial entrenchment hypothesis under the separation of ownership and control imbues corporate managers with an array of discretionary powers over certain corporate activities, such as diversifying the firm's portfolio (in order to increase their job security), shirking (Jensen \& Meckling, 1976), and undertaking fewer investment risks (Morck, Shleifer \& Vishny, 1988). Each of these discretionary behaviours can lead to present value loss for the firm (Jensen \& Meckling, 1979). Resolving or mitigating this divergence and/or realigning the interests of both sides requires close monitoring of corporate managers to (a) ensure transparency and accountability in the use of corporate resources, (b) mitigate the opportunistic proclivity of managers, (c) attenuate the inevitable conflict between shareholders and corporate managers, arising from the divergence of ownership and control, and (d) ensure that decisions and strategies taken by management have positive implications for shareholder wealth maximization.

A highly neglected area of the OPD is the option that firm performance could be a major determinant of corporate ownership. Research exploring the relation between corporate performance and ownership structure has also yielded mixed results. In particular, studies by McConnell and Servaes (1990), Cho (1998), Demsetz and Villalonga (2001), and Kapopoulos and Lazaretou (2006) do not provide strong evidence to reject or accept the hypothesis of relationship between firm performance and inside ownership (managerial equity). This, in effect, calls for further research into this phenomenon. Perhaps, the absence of any systematic method by which the relationship can be gauged makes conflicting results inevitable. A further explanation for inconsistent results may lie in the conceptual issues. For example, differences in methodology, measurement, sample and size, and the nature of firm performance and ownership structure and how the constructs are operationalized, all have conceptual underpinnings (Demsetz \& Villalonga, 2001).

In this paper, we seek to examine the relations between three dimensions of ownership structure and three dimensions of firm performance. Specifically, we examine the relation between three financial performance indicators - market price, earnings per share, and return on assets - and three ownership structures - concentrated ownership, foreign ownership, and insider ownership, using Nigerian listed firms as grounds of evidence. Our investigation seeks to provide empirical support to three possible relationships between firm performance and ownership structure: (i) the existence of a positive relationship between firm financial performance and ownership structure, suggesting that firm performance is the driving force towards the structure of ownership; (ii) lack of relationship between firm financial performance and ownership structure; and (iii) the existence of a negative relationship between firm financial performance and ownership structure.

The motivation for this line of investigation derives from the need to address the observations made by Demsetz and Villalonga (op. cit.) and to help fill the gap in empirical research on the phenomenon of interest in Africa. Furthermore, our three dimensional model of firm performance and ownership structure, as explained above, might be seen as a corrective approach to prior studies which concentrated on the reciprocal relationship between ownership structure and firm performance. Above all, this model is consistent with the view that decisive ownership structures (diffuse or concentrated, foreign or insider) are those that emerge from the interplay of market forces and market indicators of firm performance which maximize shareholders' expected returns.

The following section discusses the theoretical framework with a review of the related empirical literature. Section 3 describes the data and variables we use in our empirical analysis. Section 4 reports and discusses our findings. Section 5 concludes.

\section{Literature Review and Theoretical Framework}

\subsection{Theoretical Framework}

Demsetz and Lehn (1985) provide incipient evidence of the endogeneity of a firm's ownership structure based on the framework long established by Berle and Means. Demsetz and Lehn's research is embedded in the following three propositions: value-maximizing size of the firm, control potential, and systematic regulation. Together with the orthodox viewpoint, they offer plausible explanations to why ownership may be concentrated or diffused.

\subsubsection{Value Maximizing Size Proposition}

The value-maximizing size theory of the firm asserts that the size of firms that compete successfully in product and input markets varies within and among industries. The authors argue that "the larger the competitively viable size, ceteris paribus, the larger the firm's capital resources and, generally, the greater the market value of a given fraction of ownership" (ibid.). The implication of this theory is that the higher price of a given fraction of the firm should, in itself, reduce the degree to which ownership is concentrated. In other words, an inverse relation should subsist between the market price of shares (a financial performance measure) and ownership 
concentration.

Demsetz and Lehn (1985) further opine that risk aversion should reinforce the risk-neutral effect and attempts to preserve effective and concentrated ownership in the face of larger capital needs require a small group of owners to commit more wealth to a single enterprise. The affirmative content of the value-maximizing size theory is that as firms grow in size, their funding needs extend beyond the financial capabilities of existing shareholders who have to invest greater amounts to either maintain or obtain a given level of equity (See Welch, 2003; Tsegba \& Herbert, 2013). Demsetz and Lehn further posit that the size of firms that compete successfully in product and input markets varies with and among industries. This supports the earlier proposition that the larger the firm size, the larger the firm's capital resources and the greater the market value of its shares, ceteris paribus.

\subsubsection{Control Potential Theory}

Control potential is defined by Demsetz and Lehn (1985) as the wealth gain achievable through more effective monitoring of managerial performance by a firm's owners. The basis of the authors' argument is that the explanatory power of control potential in ownership structure would be negligible in the presence of symmetrical alignment of the managerial market with the interest of managers and shareholders. Corporate control is neither a nontrivial nor costless organizational activity. In addition to transaction and information costs associated with acquisition and maintenance of corporate control, significant regulatory costs are implicit. The presumption that the managerial labour market imperfectly disciplines erring corporate managers implies that the transaction costs impose specific identity and control potential on firms. Consequently, alterations in the ownership structure can, in part, be understood as a response to those costs. The control potential theory also takes the view that owners believe they can influence the direction of their firms and that all outcomes are neither completely random nor completely foreseeable. This notion recognizes the existence of risks, opportunities, and managerial shirking which are to some degree controllable by owners.

\subsubsection{Systematic Regulation Theory}

Systematic regulation theory posits that restriction is placed on the options available to owners, thus reducing control potential in ways that may not be reflected fully in profit instability. Demsetz and Lehn (1985) aver that regulation also provides some subsidized monitors and disciplining of the management of regulated firms. Systematic regulation may have antitrust effect and should thus moderate ownership concentration, especially if the latter is viewed as monopolistic and unfair business practice. The net impact of regulation is to encourage diffuseness of ownership in regulated industries like banks.

\subsubsection{Endogenous Ownership Structure}

The foregoing theoretical frameworks are in contrast with the orthodox view of ownership as an endogenous variable. Exogeneity of ownership structure implies that corporate ownership is determined 'outside the firm', that is, by forces external to the firm. The orthodox school of thought contends that ownership is determined by a confluence of factors derived from or originating internally within the firm, such as the industry or sector in which the firm operates, firm size, the regulatory climate, risk and the degree of financial leverage (Alonso-Bonis \& Andres-Alonso, 2007). Viewed from this lens, ownership structure would closely reflect the influence certain aspects of the firm exercise over it, including its financial performance.

\subsection{Financial Performance and Ownership Structure}

Studies that have investigated the relationship between financial performance and ownership structure are rather sparse, compared with those that seek to establish the reverse relationship. The studies include McConnel and Servaes (1990), Loderer and Martin (1997), Cho (1998), Demsetz and Villalonga (2001), Kapopoulos and Lazaretu (2006), and Farooque et al. (2007). Table 1 presents a summary with a cocktail of evidence about the connection between firm performance and ownership structure. Even though the results are mixed, the studies target insider ownership and ownership concentration where the behavior of investors, present or prospective, could be influenced by firm performance. This re-echoes the dominant role performance could play in any emerging ownership structure. 
Table 1. Summary of key research results on the relationship between firm performance and ownership structure

\begin{tabular}{|c|c|c|c|}
\hline Author/s & Title of Research & Ownership Structure & Results \\
\hline $\begin{array}{l}\text { McConnell \& } \\
\text { Servaes (1990) }\end{array}$ & $\begin{array}{l}\text { Additional Evidence on Equity } \\
\text { Ownership and Corporate Value }\end{array}$ & $\begin{array}{l}\text { 1. Insider ownership } \\
\text { 2. Concentrated ownership }\end{array}$ & $\begin{array}{l}\text { Significant curvilinear relationship between } \\
\text { firm performance and insider ownership. } \\
\text { Positive but insignificant relationship } \\
\text { between firm performance and } \\
\text { concentrated ownership }\end{array}$ \\
\hline $\begin{array}{l}\text { Loderer and } \\
\text { Martin (1997) }\end{array}$ & $\begin{array}{l}\text { Executive Stock Ownership and } \\
\text { Performance: Tracking Faint Traces }\end{array}$ & Insider ownership & $\begin{array}{l}\text { Ownership does not predict performance } \\
\text { but performance is negative predictor of } \\
\text { ownership. }\end{array}$ \\
\hline Cho (1998) & $\begin{array}{l}\text { Ownership Structure, Investment, } \\
\text { and the Corporate Value: An } \\
\text { Empirical Analysis }\end{array}$ & Insider ownership & $\begin{array}{l}\text { Firm performance affects ownership } \\
\text { structure but not vice versa. }\end{array}$ \\
\hline $\begin{array}{l}\text { Demsetz \& } \\
\text { Villalonga }(2001)\end{array}$ & $\begin{array}{l}\text { Ownership Structure \& Corporate } \\
\text { Performance }\end{array}$ & $\begin{array}{l}\text { 1. Insider ownership } \\
\text { 2. Concentrated ownership }\end{array}$ & $\begin{array}{l}\text { Negative relationship between firm } \\
\text { performance and insider ownership. }\end{array}$ \\
\hline $\begin{array}{l}\text { Kapopoulos and } \\
\text { Lazaretou (2006) }\end{array}$ & $\begin{array}{l}\text { Corporate Ownership Structure and } \\
\text { Firm Performance: Evidence from } \\
\text { Greek Firms. }\end{array}$ & $\begin{array}{l}\text { 1. Concentrated ownership } \\
\text { 2. Insider ownership }\end{array}$ & $\begin{array}{l}\text { Linear positive relationship between firm } \\
\text { performance and ownership structure. }\end{array}$ \\
\hline $\begin{array}{l}\text { Farooque et al. } \\
(2007)\end{array}$ & $\begin{array}{l}\text { Ownership Structure and Corporate } \\
\text { Performance: Evidence from } \\
\text { Bangladesh. }\end{array}$ & Insider ownership & $\begin{array}{l}\text { Performance has significant negative } \\
\text { impact on ownership. }\end{array}$ \\
\hline
\end{tabular}

\section{Methodology}

\subsection{Sample and Data}

The study sample comprises 70 companies listed on the Nigerian Stock Exchange (NSE), covering the period 1 January, 2002 to 31 December, 2007. These companies represent all firms for which financial performance and ownership data were available over the period. The firms account for slightly less than $50 \%$ of the firms listed on the NSE during the period. The combination of 70 firms and six year periods studied provides a balanced panel with 420 observations for panel data analysis. We excluded the financial sector from the study due to the turbulence and frequent policy changes by the Central Bank of Nigeria (CBN) which created discernible instability in the performances of banks during this period.

\subsection{Variable Definitions and Sources}

This study utilizes three sets of variables: dependent, independent, and control variables. The dependent variables are the corporate ownership structures that could be affected by firm performance, namely, concentrated ownership (CONCEN), insider ownership (INSIDE), and foreign ownership (FOREIG). We define CONCEN as the minimum number of shareholders that jointly control the firm. Insider ownership (INSIDE) is defined as the percentage of shares held by directors. Finally, we express FOREIG as the percentage of shares held by foreign owners. All the dependent variables are computed from the firms' annual reports and accounts.

The independent or explanatory variables are the financial performance indices. Enterprise performance is construed to mean a firm's financial viability, or the extent to which a company achieves its economic goals. Here, we use three firm performance measures which address three clientele groups: prospective investors, current investors or shareholders, and management. We focus on three measures of enterprise performance: market price per share (MPS), earnings per share (EPS), and return on assets (ROA). As suggested elsewhere (see Tsegba \& Herbert, 2013), MPS, representing the current price at which shares are traded in the stock market, is an important measure of performance from an investor's perspective because it reflects market perception of the firm value. In this study, we define MPS as price at which the shares are traded on the floor of the Nigerian Stock Exchange as at the close of the trading year, that is, $31^{\text {st }}$ December. The market prices are obtained from the NSE daily performance reports.

The EPS is a measure of an investor's returns which addresses investors' interest and concerns regarding the reward expected from their investments. The EPS is generally considered to be the single most important 
variable in determining the price of shares. In this study, we define EPS as the net profit after tax divided by the number of shares in issue. The ROA assesses managerial performance. It is a measure of how well management is using the firm's resources (assets) at their disposal for the benefit of the shareholders. We express ROA as the net profit after tax divided by the total assets. Information for the calculation of EPS and ROA is obtained from the firms' annual reports and accounts.

We further use two variables to control for firm specific factors due to the possibility that a number of factors may jointly affect ownership structure and, therefore, induce spurious correlation between them (Welch, 2003). These control variables are firm size (SIZE) and leverage (LEVER). Firm size (SIZE), measured as the natural logarithm of the firm's total assets, is a proxy for a firm's complexity (Fama \& Jensen, 1983), since the scale and complexity of a large firm could obscure our proposed relationship (see Habbash, 2012). We utilize LEVER as the second control variable to proxy for the level of firm's indebtedness because, as noted by Demsetz and Lehn (1985), ownership structure may influence firm financial structure. Again, the two control variables are computed from information obtained from the firms' annual reports and accounts.

\subsection{Regression Models}

We employ regression analysis which is one of the most widely used statistical tools in the management and social sciences. The major advantage of regression models is their power to measure the degree of association between and amongst variables and determine the extent and direction of their relationship. As indicated earlier, our investigation seeks to provide empirical support to three possible relationships between firm performance (a) and ownership structure (b); (i) positive relationship between (a) and (b); (ii) no relationship between (a) and (b); and (iii) negative relationship between (a) and (b).

We modify the econometric models of Demsetz and Villalonga (2001) as follows:

$$
\begin{aligned}
& \text { CONCEN }_{i t}=\beta_{0}+\beta_{1} \text { MPS }_{i t}+\beta_{2} \text { EPS }_{i t}+\beta_{3} R O A_{i t}+\beta_{4} S I Z E_{i t}+\beta_{5} L_{E V E R_{i t}}+e_{i t} \\
& \text { FOREIG }_{i t}=\beta_{0}+\beta_{1} \text { MPS }_{i t}+\beta_{2} E P S_{i t}+\beta_{3} R O A_{i t}+\beta_{4} S I Z E_{i t}+\beta_{5} L_{E V E R_{i t}}+e_{i t} \\
& I N S I D E_{i t}=\beta_{0}+\beta_{1} M P S_{i t}+\beta_{2} E P S_{i t}+\beta_{3} R O A_{i t}+\beta_{4} S I Z E_{i t}+\beta_{5} L E V E R_{i t}+e_{i t}
\end{aligned}
$$

Where:

$$
\begin{aligned}
& \mathrm{CONCEN}_{\text {it }}=\text { concentrated ownership structure from period } \mathrm{i} \text { to } \mathrm{t} \\
& \text { FOREIG }_{\text {it }}=\text { foreign ownership structure from period } \mathrm{i} \text { to } \mathrm{t} \\
& \mathrm{INSIDE}_{\mathrm{it}}=\text { insider ownership structure from period } \mathrm{i} \text { to } \mathrm{t} \\
& \mathrm{MPS}_{\mathrm{it}}=\text { the market price per share from period } \mathrm{i} \text { to } \mathrm{t} \\
& \mathrm{EPS}_{\mathrm{it}}=\text { earnings per share from period } \mathrm{i} \text { to } \mathrm{t} \\
& \mathrm{ROA}_{\mathrm{it}}=\text { return on assets from period } \mathrm{i} \text { to } \mathrm{t} \\
& \mathrm{SIZE}_{\mathrm{it}}=\text { firm size from period } \mathrm{i} \text { to } \mathrm{t} \\
& \mathrm{LEVER}_{\text {it }}=\text { leverage or debt to equity ratio from period } \mathrm{i} \text { to } \mathrm{t}
\end{aligned}
$$

$\beta_{0}, \beta_{1}, \beta_{2} \ldots \beta_{\mathrm{n}}$ are the correlation coefficients.

$e_{i}$ is the random variable or error term that accounts for the variability in the dependent variable which cannot be explained by the linear effect of the independent variables.

We begin by addressing some critical issues that potentially affect the outcome of the regression results. First, we conduct skewness ratios to ascertain the normality of the data used for the analysis. Second, we perform correlation analysis to establish the short-run relationship between the independent and control variables. It has been suggested that checks for multicollinearity among the explanatory variables generally are necessary because high correlations cause problems about the relative contribution of each predictor to the success of the model (Barako \& Tower, 2006).

\subsubsection{Normality Tests}

The summary of the skewness ratio analysis presented in Table 2 shows that, except for FOREIG and ROA, all the other variables are not normally distributed. All the variables with a skewness ratio in excess of plus or minus 1.96 (at the 5\% level of significance) are not normally distributed. We have taken the natural logs of these variables to normalize them prior to regression analysis. 
Table 2. Results of Skewness ratio analysis

\begin{tabular}{lccc}
\hline Variable & Skewness & Std Error of Skewness & Ratio \\
\hline CONCEN & 4.974 & 0.119 & $41.7983^{*}$ \\
INSIDE & 2.371 & 0.119 & $19.9244^{*}$ \\
FOREIG & 0.002 & 0.119 & 0.0168 \\
MPS & 2.893 & 0.119 & $24.3109^{*}$ \\
EPS & 2.471 & 0.119 & $20.7647^{*}$ \\
ROA & -0.037 & 0.119 & $-0.3109^{*}$ \\
SIZE & 3.238 & 0.119 & $27.2101^{*}$ \\
LEVER & 3.462 & 0.119 & $29.0924^{*}$
\end{tabular}

* denotes variables that are not normally distributed.

\subsubsection{Correlations and Multicollinearity Tests}

Table 3 shows the correlation matrix for the variables under investigation. The correlation that is worthy of note is the 0.667 correlation between MPS and EPS, which is however below the maximum correlation of 0.8 allowable (see Barako \& Tower; 2006; Gujarati \& Sangeetha, 2007). The correlation analysis suggests that multicollinearity does not present a challenge in this study. Besides, none of the remaining variables are correlated to an extent that merits noting.

Table 3. Correlation matrix

\begin{tabular}{|c|c|c|c|c|c|c|c|c|}
\hline Variable & CONCEN & INSIDE & FOREIG & MPS & EPS & ROA & SIZE & LEVER \\
\hline CONCNEN & 1.000 & & & & & & & \\
\hline INSIDE & -.089 & 1.000 & & & & & & \\
\hline FOREIG & -.206 & -.291 & 1.000 & & & & & \\
\hline MPS & .019 & -.232 & .310 & 1.000 & & & & \\
\hline EPS & .003 & -.190 & .246 & .667 & 1.000 & & & \\
\hline ROA & -.026 & -.012 & .055 & .286 & .358 & 1.000 & & \\
\hline SIZE & .134 & -.210 & .217 & .521 & .460 & .179 & 1.000 & \\
\hline LEVER & .170 & -.225 & .165 & .586 & .476 & .110 & .577 & 1.000 \\
\hline
\end{tabular}

\section{Analysis of Results and Discussions}

\subsection{Descriptive Statistics}

We now discuss the central findings of our study. The descriptive statistics in Table 4 highlight the basic features of the data analyzed in this study. The table shows wide dispersions among MPS and SIZE, which implies the presence of small and large firms in the study sample. Taking the natural logs of these variables to reduce the adverse effect of outliers or influential points in data analysis, we notice the absence of insider ownership, foreign ownership and leverage in a number of firms. This seems absurd, especially for insider ownership, which signifies the absence of management interest in the firms they manage. Foreign ownership (FOREIG), ROA and LEVER present least dispersions. 
Table 4. Descriptive statistics

\begin{tabular}{lcccccc}
\hline Variable & N & Minimum & Maximum & Range & Mean & Std Dev. \\
\hline CONCNEN & 420 & 1 & 593 & 592 & 24.5000 & 86.9870 \\
INSIDE & 420 & 0.0000 & 0.8136 & .8136 & 0.0801 & 0.1483 \\
FOREIG & 420 & 0.0000 & 0.8844 & .8844 & 0.3165 & 0.2673 \\
MPS & 420 & 27 & 26,355 & 26,328 & $2,158.7700$ & $4,285.2530$ \\
EPS & 420 & -930.8600 & $1,261.32$ & $2,192.18$ & 100.2887 & 228.5400 \\
ROA & 420 & -1.3074 & 0.3595 & 1.6669 & 0.0364 & 0.1329 \\
SIZE & 420 & 67,310 & $162,684,055$ & $162,616,745$ & $11,032,086$ & $18,514,494$ \\
LEVER & 420 & 0.0000 & 55.0162 & 55.0162 & 3.7384 & 6.9841 \\
\hline
\end{tabular}

\subsection{Regression Results}

Table 5 presents the summary of the regression results for all the variables. The adjusted $\mathrm{R}^{2}$, which is a measure of the strength of the model, is $2.3 \%$ for CONCEN, $15.6 \%$ for FOREIG and $17.3 \%$ for INSIDE. The values for adjusted $\mathrm{R}^{2}$ are rather low, suggesting that factors other than those included in the model offer plausible explanation for the relationship between firm performance and ownership structure. However, the F-Statistics, which is a measure of the reliability of the model, is significant at $1 \%$ level for all the three ownership structures investigated. This affirms the validity of the model.

Table 5 reports that: (1) MPS is both negative and not significantly related to CONCEN and INSIDE. However, a significant positive relationship exists between MPS and foreign ownership. (2) A significant but negative relationship exists between EPS and INSIDE. The relationship between EPS and CONCEN is negative but not significant. On the other hand, EPS and FOREIG present positive relationship although not significant. (3) The relationship between ROA and CONCEN and between ROA and FPREIG is negative but not significant. But, there is a significant positive relationship between ROA and INSIDE. (4) The relationship between SIZE and CONCEN is negative but not significant. There is a significant positive relationship between SIZE and FOREIG. On the other hand, a significant negative relationship exists between SIZE and INSIDE. (5) LEVER is significantly and positively related to CONCEN; it is, however, positively but insignificantly related to INSIDE; and a negatively but insignificantly related to FOREIG.

Table 5. OLS estimates for all variables

\begin{tabular}{lccc}
\hline Variable & CONCEN & FOREIG & INSIDE \\
\hline MPS & -0.137 & 0.169 & -0.145 \\
EPS & $(-1.685)^{*}$ & $(2.227)^{* *}$ & $(-1.939)^{*}$ \\
& -0.012 & 0.042 & -0.131 \\
ROA & $(-0.176)$ & $(0.678)$ & $(-2.139)^{* *}$ \\
& -0.055 & -0.072 & 0.111 \\
SIZE & $(-1.031)$ & $(-1.448)$ & $(2.255)^{* *}$ \\
& -0.033 & 0.320 & -0.261 \\
LEVER & $(-0.512)$ & $(5.268)^{* * *}$ & $(-4.339)^{* * *}$ \\
No. of observations & 0.206 & -0.102 & 0.037 \\
Adjusted ${ }^{2}$ & $(3.315)^{* * *}$ & $(-1.765)^{*}$ & $(0.646)$ \\
F-Statistics & 420 & 420 & 420 \\
t-statistics in parentheses. & 0.023 & 0.156 & 0.173 \\
${ }^{*}$ Significant at $10 \%$ level; ${ }^{* *}$ Significant at $5 \%$ level; ${ }^{* * *}$ Significant at $1 \%$ level. & $16.536 * * *$ & $18.584 * * *$
\end{tabular}




\subsection{Robustness Checks}

In order to gauge the robustness of the results, we have adopted a stepwise regression approach by eliminating SIZE first, followed by substituting SIZE with LEVER, and finally by eliminating both control variables (SIZE and LEVER). As suggested by Argyrous (2006), stepwise regressions enable us to select the specific variables that actually do have significant influence. The results of the stepwise regression analysis excluding SIZE are presented in Table 6 below.

Table 6. OLS estimates without firm size

\begin{tabular}{|c|c|c|c|}
\hline Variable & CONCEN & FOREIG & INSIDE \\
\hline \multirow[t]{2}{*}{ MPS } & -0.150 & 0.169 & -0.247 \\
\hline & $(-1.944)^{*}$ & $(2.227)^{* *}$ & $(-3.400)^{* * *}$ \\
\hline \multirow[t]{2}{*}{ EPS } & -0.020 & 0.042 & -0.193 \\
\hline & $(-0.305)$ & $(0.678)$ & $(-3.180)^{* * *}$ \\
\hline \multirow[t]{2}{*}{ ROA } & -0.056 & -0.072 & 0.103 \\
\hline & $(-1.052)$ & $(-1.448)$ & $(2.049)^{* *}$ \\
\hline \multirow[t]{2}{*}{ LEVER } & 0.201 & -0.102 & 0.002 \\
\hline & $(3.279)^{* * *}$ & $(-1.765)^{*}$ & $(0.038)$ \\
\hline No. of observations & 420 & 420 & 420 \\
\hline Adjusted $\mathrm{R}^{2}$ & 0.025 & 0.156 & 0.138 \\
\hline F-Statistics & $3.707 * * *$ & 16.536 *** & 17.761 *** \\
\hline
\end{tabular}

$\mathrm{t}$-statistics in parentheses.

*Significant at $10 \%$ level; **Significant at $5 \%$ level; ***Significant at $1 \%$ level.

The findings in Table 6 differ from those of Table 5 in two respects. First, INSIDE is now significantly but negatively related to MPS. Second, EPS is negatively but significantly related to INSIDE. There are no significant variations in the adjusted $\mathrm{R}^{2}$. The F-Statistics also remain significant at $1 \%$ level. We further excluded LEVER and included SIZE in the OLS equations to dictate the separate effect of this control variable (SIZE) in the analysis. The exclusion of SIZE does not have significant effect on the results, presented in Table 7 below.

Table 7. OLS Estimates without LEVER

\begin{tabular}{|c|c|c|c|}
\hline Variable & CONCEN & FOREIG & INSIDE \\
\hline \multirow[t]{2}{*}{ MPS } & -0.033 & 0.117 & -0.127 \\
\hline & $(-0.439)$ & $(1.673)^{*}$ & $(-1.833)^{*}$ \\
\hline \multirow[t]{2}{*}{ EPS } & 0.003 & 0.035 & -0.128 \\
\hline & $(0.041)$ & $(0.562)$ & $(-2.103)^{* *}$ \\
\hline \multirow[t]{2}{*}{ ROA } & -0.003 & -0.060 & 0.106 \\
\hline & $(-0.047)$ & $(1.212)$ & $(2.188)^{* *}$ \\
\hline \multirow[t]{2}{*}{ SIZE } & -0.003 & 0.305 & -0.255 \\
\hline & $(-0.047)$ & $(5.058)^{* * *}$ & $(-4.294)^{* * *}$ \\
\hline No. of observations & 420 & 420 & 420 \\
\hline Adjusted $\mathrm{R}^{2}$ & 0.000 & 0.152 & 0.138 \\
\hline F-Statistics & $0.994 * * *$ & $19.789 * * *$ & $17.761 * * *$ \\
\hline
\end{tabular}

$\mathrm{t}$-statistics in parentheses.

*Significant at $10 \%$ level; **Significant at $5 \%$ level; ***Significant at $1 \%$ level.

We then deleted all the control variables to ascertain their effect on the model. The OLS results are presented in Table 8 below. We notice a fall in the Adjusted $\mathrm{R}^{2}$ compared with the original results in Table 5, although the F-Statistics still remain significant at the $1 \%$ level. 
Table 8. OLS estimates without control variables

\begin{tabular}{lccc}
\hline Variable & CONCEN & FOREIG & INSIDE \\
\hline MPS & -0.035 & 0.259 & -0.247 \\
& $(-0.500)$ & $(3.929)^{* * *}$ & $(-3.400)^{* * *}$ \\
EPS & -0.020 & 0.112 & -0.193 \\
& $(-0.305)$ & $(1.816)^{*}$ & $(-3.180)^{* * *}$ \\
ROA & -0.056 & -0.055 & 0.103 \\
& $(-1.052)$ & $(-1.086)$ & $(2.049)^{* *}$ \\
No. of observations & 420 & 420 & 420 \\
Adjusted R & 0.002 & 0.102 & 0.138 \\
F-Statistics & $1.328 * * *$ & $16.862 * * *$ & $17.761 * * *$ \\
\hline
\end{tabular}

t-statistics in parentheses.

*Significant at $10 \%$ level; **Significant at $5 \%$ level; ***Significant at $1 \%$ level.

\subsection{Discussion of Results}

The results presented in Table 9 below summarize the relationship between financial performance and ownership structure with and without the control variables. As stated earlier, the use of stepwise regressions is to provide robustness check on the results obtained from the original OLS (Table 5).

Table 9. Summary of OLS results

\begin{tabular}{|c|c|c|c|c|c|c|}
\hline \multirow[t]{2}{*}{ Variable } & \multicolumn{3}{|c|}{ With control variables } & \multicolumn{3}{|c|}{ Without control variables } \\
\hline & CONCEN & FOREIG & INSIDE & CONCEN & FOREIG & INSIDE \\
\hline MPS & $\begin{array}{l}\text { Negative but not } \\
\text { significant }\end{array}$ & $\begin{array}{l}\text { Significant positive } \\
\text { relationship }\end{array}$ & $\begin{array}{l}\text { Negative but not } \\
\text { significant }\end{array}$ & $\begin{array}{l}\text { Negative but } \\
\text { not significant }\end{array}$ & $\begin{array}{l}\text { Significant positive } \\
\text { relationship }\end{array}$ & $\begin{array}{l}\text { Significant negative } \\
\text { relationship }\end{array}$ \\
\hline EPS & $\begin{array}{l}\text { Negative but not } \\
\text { significant }\end{array}$ & $\begin{array}{l}\text { Positive but not } \\
\text { significant }\end{array}$ & $\begin{array}{l}\text { Negative but not } \\
\text { significant }\end{array}$ & $\begin{array}{l}\text { Negative but } \\
\text { not significant }\end{array}$ & $\begin{array}{l}\text { Positive but not } \\
\text { significant }\end{array}$ & $\begin{array}{l}\text { Significant negative } \\
\text { relationship }\end{array}$ \\
\hline ROA & $\begin{array}{l}\text { Negative but not } \\
\text { significant }\end{array}$ & $\begin{array}{l}\text { Negative but not } \\
\text { significant }\end{array}$ & $\begin{array}{l}\text { Significant positive } \\
\text { relationship }\end{array}$ & $\begin{array}{l}\text { Negative but } \\
\text { not significant }\end{array}$ & $\begin{array}{l}\text { Negative but not } \\
\text { significant }\end{array}$ & $\begin{array}{l}\text { Significant positive } \\
\text { relationship }\end{array}$ \\
\hline SIZE & $\begin{array}{l}\text { Negative but not } \\
\text { significant }\end{array}$ & $\begin{array}{l}\text { Significant positive } \\
\text { relationship }\end{array}$ & $\begin{array}{l}\text { Significant negative } \\
\text { relationship }\end{array}$ & Not applicable & Not applicable & Not applicable \\
\hline LEVER & $\begin{array}{l}\text { Positive but not } \\
\text { significant }\end{array}$ & $\begin{array}{l}\text { Negative but not } \\
\text { significant }\end{array}$ & $\begin{array}{l}\text { Positive but not } \\
\text { significant }\end{array}$ & Not applicable & Not applicable & Not applicable \\
\hline
\end{tabular}

Table 9 presents a number of interesting observations. First, we note the negative relationship between firm performance, denoted by MPS, EPS \& ROA, and ownership concentration. These findings are inconsistent with those obtained by McConnel and Servaes (1990), and Kapopoulos and Lazaretou (2006). The possible explanation for this inconsistency could be the different measures of ownership concentration used by these studies. We measure ownership concentration as the minimum number of shareholders that control the firm whereas they measured it as the holdings of the first 5 and 10 largest shareholders. Furthermore, their measures of firm performance are different from the ones we used in our study.

Second, we find (i) a significant positive relationship between firm performance and foreign ownership (MPS); (ii) positive but not significant relation between EPS and foreign ownership, and (iii) a negative but not significant relationship between ROA and foreign ownership. Though there is paucity of empirical work on the relation between firm performance and foreign ownership, one major observation could be made about these results. Foreign ownership in itself is a market price driven ownership structure in especially emerging markets. Foreign ownership adumbrates eclectic advantages in ownership and internalization respects, such as managerial expertise, access to production technology and capital as well as markets. With their competitive advantage, it is plausible to expect a significant positive relationship between firm performance and foreign ownership. 
Third, a negative but insignificant relationship exists between INSIDE and MPS, and EPS. The relationship is significant though when the control variables are removed from the model. The overwhelming evidence from this study is that a relationship exists between firm performance and INSIDE (insider ownership). These findings are consistent with the view that firm performance is a negative predictor of insider ownership (see Loderer \& Martin, 1997; Demsetz \& Villalongo, 2001; and Farooque, Zijl, Dunstan, \& Karim, 2007). This consistency in results is without prejudice to the variation in firm performance measures adopted by the different studies. Demsetz and Villalonga (2001), for instance, used Tobin's $Q$ and accounting profit rate as performance measures. Kapopoulos and Lazaretou (2006), however, found a positive relationship between firm performance and insider ownership structure. While we agree with the proposition that ownership structure is chosen so as to maximize firm performance (Demsetz \& Villalonga, 2001), our findings lead us to infer that corporate managers seem to be reluctant or skeptical to hold shares in their underperforming firms.

\subsection{Managerial Implications of Contrarian Insider Ownership Interests}

There is some support in our study for the notion that management is less interested in holding shares in their underperforming firms. We do not have convincing explanations for this, but given that the plenitude of research in accounting, finance economics, and management on corporate governance has not yielded clarity or consensus to the ownership-performance debate (OPD), our finding has confounding managerial implications. First, the evidence of our study challenges the average conclusion of the managerial ownership cum alignment thesis (Dalton, Daily, Certo, \& Roengpitya, 2003). The prevailing view is that insider equity ownership putatively helps to align the interests of managers and shareholders. As such, they (managers) are predisposed to making decisions that are consistent with interests of the broader constituency of shareholders, inclusive of them. Research from various disciplines, such as finance (Agrawal \& Knoeber, 1996), economics (Himmelberg, Hubbard, \& Palia, 1999), law (Perry \& Zenner, 2000), and strategy (Dalton, Daily, Certo, \& Roengpitya, 2003), has examined this phenomenon in terms of how and when insider ownership supports alignment between the interests of managers and owners. The appeal of this school of thought, which is rooted in Jensen and Meckling's (1976) agency theory, is that the higher the managerial (insider ownership) stakes in a firm, the more likely they will deploy corporate resources in value-maximizing decisions, that is, towards long-term profitability, and the less likely they will shirk from executing their fiscal and strategic responsibilities (Connelly, Hoskisson, Tihanyi, \& Certo, 2010).

This managerial ownership-alignment perspective is not generally shared by researchers such as Morck, Shleifer and Vishny (1988) who note the potential adversarial effects of managerial (insider) ownership. The contention is that high levels of ownership may increase executive power, which may lead them to become entrenched within the firm. The managerial entrenchment hypothesis posits that managers tend to consume more perquisites and/or reduce the firm's risk profile to protect their own interests. Other strands of research show that managerial ownership may lead to (a) greater risk taking (Rajgopal \& Shevlin, 2002), (b) goal misalignment with respect to such issues as backdating of stock options (Bhattacharya, 1981), and (c) earnings manipulation, and dividend policies (Devers, Cannella, Reilly \& Yoder, 2007).

These contrasting perspectives are consistent with the mixed empirical results. For example, both our finding and the ownership-alignment studies are in contrast with Demsetz and Villalongo's (2001) suggestion that management prefers to hold fewer shares when firms seem to be doing well, perhaps selling them during good times in the expectation that current good performance will be followed by poorer performance. A possible explanation is predicated on the role of risk in explaining variations in ownership structure (ibid.). Our presumption, therefore, is that firms that exhibit low performance are less inclined to their management having a stake in them. If also the firm is in high risk business and management is both risk averse and feels that it already has invested specific human capital in the firm, this may be a plausible reason to loathe equity interest in their firm.

Another plausible explanation derives from the information asymmetry condition which reduces the distribution of information between parties under a unified governance structure. The parties here are managers and owners. Managers have both access to firm-specific information which may not be available to other investors costlessly and some element of control over firm actions and resources. They naturally will utilize such insider information and their entrenched discretionary power to their opportunistic advantage, including aversion to invest in their underperforming firm. In general, we aver that although managerial ownership and control vary considerably with respect to their equity positions, the influence of these variations on firm actions vis-à-vis other ownership structures and firm performance however remains an empirical issue. 


\section{Summary and Conclusions}

This study is motivated by the unending debate in the corporate finance literature about the connection between ownership structure and firm performance, what we characterize as the ownership-performance debate (OPD). Ever since Berle and Means (1932) postulated the existence of an inverse relationship between diffuse ownership and firm performance, most studies have treated ownership structure as a corporate governance mechanism. There is little attention to the possibility that firm performance could in fact impact ownership structure. In this study, we have isolated three measures of enterprise performance, namely, market price per share (MPS), earnings per share (EPS) and return on assets (ROA). Each of these measures is carefully selected to represent a clientele group that could invest in the firm. The results from our study are largely consistent with those of prior studies. In the main, we find that: (a) a negative relationship exists between firm performance and concentrated ownership; (b) an insignificant relationship exists between firm performance and foreign ownership; (c) there is a negative and significant relationship between firm performance and insider ownership.

Both from our study and some of the studies preceding it, evidence about the relationship between firm performance and ownership structure remains equivocal and inconclusive. In general, although managerial ownership and control vary considerably with respect to their equity positions, the influence of these variations on firm actions vis-à-vis other ownership structures and firm performance remains an empirical issue. Thus, regardless of the methodological rigour, no categorical inferences can be drawn at present either from this study or previous studies to justify closure. Without question, therefore, the OPD remains an empirical issue and calls attention to more research.

\section{References}

Adenikinju, O., \& Ayorinde, F. (2001). Ownership Structure, Corporate Governance and Corporate Performance: The Case of Nigerian Quoted Companies. Report presented at the AERC biannual research workshop, Nairobi, May.

Agrawal, A., \& Knoeber, C. R. (1996). Firm performance and mechanisms to control agency problems between managers and shareholders. Journal of Financial and Quantitative Analysis, 31, 377-397. http://dx.doi.org/10.2307/2331397

Alonso-Bonis, S., \& Andrés-Alonso, P. (2007). Ownership structure and performance in large Spanish companies: Empirical evidence in the context of an endogenous relation. Corporate Ownership and Control, 4(4), 206-216.

Argyrous, G. (2006). Statistics for Research. London: Sage Publications.

Barako, D. G., \& Tower, G. (2006). Corporate Governance and Bank Performance: Does Ownership Matter? Evidence from Kenyan Banking Sector. Corporate Ownership and Control, 4(2), 133-144.

Berle, A. A., \& Means, G. C. (1932). The Modern Corporation and private property. New York. Retrieved from http://www.repository.law.indiana.edu/cgi/viewcontent.cgi?article=5120content=ilj

Bhattacharya, S. (1981). Notes on multiperiod valuation and the pricing of options. Journal of Finance, 36, 163-180. http://dx.doi.org/10.1111/j.1540-6261.1981.tb03541.x

Cho, M. H. (1988). Ownership Structure, Investment, and the Corporate Value: An Empirical Analysis. Journal of Financial Economics, 47, 103-121. http://dx.doi.org/10.1016/S0304-405X(97)00039-1

Connelly, B. L., Hoskisson, R. E., Tihanyi, L., \& Certo, S. T. (2010). Ownership as a Form of Corporate Governance. Journal of Management Studies, 47(8), 1561-1589. http://dx.doi.org/10.1111/j.1467-6486.2010.00929.x

Dalton, D., Daily, C., Certo, S. T., \& Roengpitya, R. (2003). Meta-analysis of financial performance and equity: fusion or confusion? Academy of Management Journal, 46, 13-26. http://dx.doi.org/10.2307/30040673

Demsetz, H., \& Lehn, K. (1985). The structure of corporate ownership: Causes and consequences. Journal of Political Economy, 93, 1155-1177. http://dx.doi.org/10.1086/261354

Demsetz, H., \& Villalonga, B. (2001). Ownership structure and corporate performance. Journal of Corporate Finance, 7, 209-233. http://dx.doi.org/10.1016/S0929-1199(01)00020-7

Devers, C., Cannella, A. A., Reilly, G. P., \& Yoder, M. E. (2007). Executive compensation: a multidisciplinary review and synthesis of recent developments. Journal of Management, 33, 1016-1072. http://dx.doi.org/10.1177/0149206307308588

Fama, E. F., \& Jensen, M. C. (1983). Separation of Ownership and Control. Journal of Law and Economics, 26, 
301-325. http://dx.doi.org/10.1086/467037

Farooque, O. A., Zijl, T. V., Dunstan, K., \& Karim, A. W. (2007). Ownership structure and corporate performance: Evidence from Bangladesh. Asian Journal of Accounting \& Economics, 14, 127-150. http://dx.doi.org/10.1080/16081625.2007.9720792

Gujarati, D. N., \& Sangeetha. (2007). Basic Econometrics. Singapore: McGraw-Hill International Edition.

Habbash, M. (2102). Earnings management, audit committee effectiveness and the role of block holders ownership: Evidence from UK large firms. Journal of Governance and Regulation, 1(4), 100-116.

Himmelberg, C. P., Hubbard, R. G., \& Palia, D. (1999). Understanding the determinants of managerial ownership and the link between ownership and performance. Journal of Financial Economics, 53, 353-384. http://dx.doi.org/10.1016/S0304-405X(99)00025-2

Jensen, M. C., \& Meckling, W. H. (1976). Theory of the firm: Managerial behaviour, agency costs, and ownership structure. Journal of Financial Economics, 3, 305-360. http://dx.doi.org/10.1016/0304-405X(76)90026-X

Jensen, M. C., \& Meckling. W. E. (1979). Rights and production functions: An application to labour-managed firms and Codetermination. Journal of Business, 52(4), 469-506. http://dx.doi.org/10.1086/296060

Kapopoulos, P., \& Lazaretou, S. (2006). Corporate Ownership Structure and Firm Performance: Evidence from Greek Firms. Bank of Greece Working Paper No. 37, April. Retrieved from http://www.bankofgreece.gr/BogEkdoseis/Paper200637.pdf

Loderer, C., \& Martin, K. (1997). Executive stock ownership and performance: Tracking faint traces. Journal of Financial Economics, 45, 223-255. http://dx.doi.org/10.1016/S0304-405X(97)00017-2

McConnell, J. J., \& Servaes, H. (1990). Additional evidence on equity ownership and corporate value. Journal of Financial Economics, 27(2), 595-613. http://dx.doi.org/10.1016/0304-405X(90)90069-C

Morck, R., Shleifer, A., \& Vishny, R. W. (1988). Management ownership and market valuation: An empirical analysis. Journal of Financial Economics, 20, 293-315. http://dx.doi.org/10.1016/0304-405X(88)90048-7

Perry, T., \& Zenner, M. (2000). CEO compensation in the 1990s: Shareholder alignment or Shareholder expropriation? Wake Forest Law Review, 35, 123-152.

Pivovarsky, A. (2003). Ownership concentration and performance in Ukraine's privatized enterprises. IMF Staff Papers, 50(1), 10-42. Retrieved from http://www.imf.org/external/pubs/ft/staffp/2003/01/PDF/pivor.pdf

Rajgopal, S., \& Shevlin, T. (2002). Empirical evidence on the relation between stock option compensation and risk taking. Journal of Accounting and Economics, 33, 145-71. http://dx.doi.org/10.1016/S0165-4101(02)00042-3

Sanda, A., Mikailu, A. S., \& Garba, T. (2005). Corporate governance mechanisms and firm financial performance in Nigeria. AERC Research Paper 149, African Economic Research Consortium, Nairobi. Retrieved from http://kore.kmi.open.ac.uk

Tsegba, I. N., \& Herbert, W. E. (2011). The Relationship between Ownership Structure and Firm Performance: Evidence from Nigerian Listed Companies. African Journal of Accounting, Economics, Finance and Banking Research, 7(7), 51-63.

Tsegba, I. N., \& Herbert, W. E. (2013). Corporate Governance, Ownership Structure and Firm Performance. Research Journal of Finance and Accounting, 4(5), 23-38.

Welch, E. (2003). The relationship between ownership structure and performance in listed Australian companies. Australian Journal of Management, 28(3), 287-305. http://dx.doi.org/10.1177/031289620302800304

\section{Copyrights}

Copyright for this article is retained by the author(s), with first publication rights granted to the journal.

This is an open-access article distributed under the terms and conditions of the Creative Commons Attribution license (http://creativecommons.org/licenses/by/3.0/). 